\title{
Variation of structures of ingredients of desiccated coconut during hydrolysis by hydrochloric acid at low temperature
}

\author{
Jian XIONG ${ }^{1}$, Hengyuan WU1 ${ }^{1}$ Jun $\mathrm{YE}^{2 *}$
}

\begin{abstract}
Owing to the high content of lignocellulose, desiccated coconut become a healthy material for dietary fiber supplementation. In this study, the changes in solubility of the fibers of desiccated coconut were evaluated. The changes of the pHs and weight losses were studied. Furthermore, variations of the ingredient structures of desiccated coconut by hydrolysis by hydrochloric acid were characterized by Fourier transform infrared spectroscopy (FTIR), X-ray diffraction (XRD) and scanning electron microscopy (SEM). After hydrolysis $30 \mathrm{~s}$, the $\mathrm{pHs}$ of all systems increased, while six hours later, the $\mathrm{pH}$ of only system with initial $\mathrm{pH}=1.00$ decreased. The decline of $\mathrm{pH}$ only existed in hydrolysis systems with initial $\mathrm{pH}=1.00$, there is no relevant with the quantities of desiccated coconut. The lower initial pH of hydrolysis system was, the less the intrinsic viscosity of the desiccated coconut after hydrolysis was, the small the crystallinity was. After hydrolysis, the microstructure of the desiccated coconut become looser, and the secondary structure of the coconut protein became more stable and ordered. The results suggest that the hydrolysis of desiccated coconut mainly occurred in the branched chain and the non-crystalline region of lignocellulose, which transforms some insoluble dietary fiber into soluble dietary fiber. This improves the nutritional value of desiccated coconut.
\end{abstract}

Keywords: coconut; hydrolysis; dietary fiber.

Practical Application: Providing a scientific data for desiccated coconut as a dietary fiber supplement and functional food additive.

\section{Introduction}

Coconut (Cocos nucifera L.: Arecaceae) is one of the most popular food and energy crops in all over the world, especially in several south-east Asian countries and regions, and is well known as the "tree of life" (DebMandal \& Mandal, 2011). China has abundant coconut resources, and it is estimated that about $11700 \mathrm{t}$ of dried coconut meal was generated only in Taiwan in 2012 (Khuwijitjaru et al., 2014). Desiccated coconut is a processed product from coconut meal. Because of its unique coconut flavor, desiccated coconut is widely used in food products, such as bakery products and sauces.

Desiccated coconut has a great nutritional value containing $68.99 \%$ carbohydrates, $25.59 \%$ fat, and $0.85 \%$ protein (Khuwijitjaru et al., 2012). Carbohydrates, the largest ingredients part of desiccated coconut, includes cellulose, hemicellulose, mannose, glucose, manno-oligosaccharides and insoluble pectin, etc. (Pham \& Rosario, 1983). Most of the carbohydrates are defined to dietary fiber which is not hydrolyzed by the endogenous enzymes in human small intestine (Marotti et al., 2012; Yapo \& Koffi, 2008). Some researches revealed that in addition to lower risk of death from heart disease, adequate consumption of fiber-containing foods was also associated with reduced incidence of infectious and respiratory illnesses, and reduced risk of high blood pressure, high cholesterol, diabetes and colon cancer (Brown et al., 1999; Kaczmarczyk et al., 2012; Park et al, 2011; Trinidad et al., 2006).
Owing to the high content of dietary fiber, desiccated coconut is promising a kind of dietary fiber supplementations. The use of desiccated coconut will significantly improve its additional value and promote the development of the coconut industry.

Acid hydrolysis is an important method to modify the physiochemical properties of dietary fiber and transform insoluble dietary fiber. Khuwijitjaru and his co-workers (Khuwijitjaru et al., 2014) hydrolyzed coconut meal in $100-300^{\circ} \mathrm{C}$ subcritical water, which showed that the polysaccharides in coconut meal were translated into mannose, glucose, and manno-oligosaccharides with various degrees of polymerization. Thongsook (Thongsook \& Chaijamrus, 2014) reported that copra meal treated in $0.5 \%-1.0 \% \mathrm{HCl}$ at $90^{\circ} \mathrm{C}$ led to depolymerization of hemicellulose and insoluble pectic substances to increase bulk density and soluble dietary fiber content. Pham (Pham \& Rosario, 1983) showed that coconut protein was decomposed into amino acids in $6 \mathrm{~mol} / \mathrm{L} \mathrm{HCl}$ at $95^{\circ} \mathrm{C}$. The production of amino acids was affected significantly by acid concentration, reaction time, and temperature.

These studies above mentioned carried on at high temperature. The results from these studies had great benefit for understanding ingredients and their structures. However, there is no help to explain how degradation in human stomach environment during digestion, because the physiological $\mathrm{pH}$ of human fluid

${ }^{1}$ School of Food Science and Engineering, South China University of Technology, Guangzhou 510640, China

${ }^{2}$ State Key Laboratory of Pulp and Paper Engineering, South China University of Technology, Guangzhou 510640, China

*Corresponding author: jye@scut.edu.cn 
gastric can range from 1.50 to 3.50 and it works at around $37^{\circ} \mathrm{C}$ (Corcoran et al., 2007; Marieb \& Hoehn, 2010; Silva et al., 2016). According to the United States Pharmacopoeia (The United States Pharmacopeia, 1995), standard simulated gastric fluid is consists of $3.2 \mathrm{mg} / \mathrm{mL}$ pepsin in $0.03 \mathrm{M} \mathrm{NaCl}$ at $\mathrm{pH} 1.20$ (hydrochloric acid is used). However, the molecules that are considered to be "dietary fiber" are so because humans lack the necessary enzymes to split the $\beta$-glycosidic bond and they reach the large intestine (Gallaher, 2006).

In this work, we simplified hydrolysis system just containing hydrochloric acid with $\mathrm{pH}=1.00-4.00$. All enzymes were omitted from the hydrolysis system to avoid providing possible degradation of dietary fiber (Lalush et al., 2005). This may be beneficial for reducing the impact of unrelated factors and explaining how to transform insoluble dietary fiber into soluble dietary fiber by hydrochloric acid hydrolysis. This research provides a scientific basis for desiccated coconut as a dietary fiber supplement and functional food additive.

\section{Materials and methods}

\subsection{Materials}

Desiccated coconut was produced in Hainan Province and purchased from a supermarket located in Guangzhou. Hydrochloric acid, cupric hydroxide, ethylenediamine (all were analytical grade) were obtained from Guangzhou Chemical Reagent Factory. Cupriethylenediamine was prepared according to TAPPI T 230 om-08.

\subsection{Preparation of defatted desiccated coconut (DDC)}

To eliminate fat, dried desiccated coconut (100 g) was immersed in ethanol (1 L) for $48 \mathrm{~h}$ and replaced with fresh ethanol every $12 \mathrm{~h}$. After separating the coconut from ethanol, the defatted desiccated coconut was kept in a $60^{\circ} \mathrm{C}$ oven for $4 \mathrm{~h}$ to remove ethanol.

\subsection{Hydrolysis by hydrochloric acid at low temperature}

Hydrolysis of DDC was performed in $50 \mathrm{~mL}$ hydrochloric acid in a water bath at $37^{\circ} \mathrm{C}$ with slow magnetic stirring. The $\mathrm{pH}$ of digestive system was determined after $30 \mathrm{~s}, 1.5 \mathrm{~h}, 3 \mathrm{~h}$, $4.5 \mathrm{~h}$, and 6 h. $\Delta \mathrm{pH}=\mathrm{pH}-\mathrm{pH}_{0}$, where $\mathrm{pH}_{0}$ and $\mathrm{pH}$ were the $\mathrm{pH}$ value before and after hydrolysis, respectively. After vacuum filtration, the defatted desiccated coconut was dried in a hot-air oven at $60^{\circ} \mathrm{C}$ until constant weight. Weight loss was calculated as $\mathrm{w} \%=\left(\mathrm{m}_{0}-\mathrm{m}\right) / \mathrm{m}_{0}$, where $\mathrm{m}_{0}$ and $\mathrm{m}$ were the weight of the defatted desiccated coconut before and after hydrolysis respectively. Experimental conditions and the corresponding label of samples were shown in Table 1.

\subsection{Structures of ingredients of desiccated coconut}

FTIR spectroscopic measurements

Infrared spectra of DDC, DDC-1, and DDC-2 were recorded on a FTIR spectrometer (Bruker TENSOR27, Germany) with $\mathrm{KBr}$ pellets. Spectra were scanned between 4000 and $400 \mathrm{~cm}^{-1}$

\section{Analysis of protein conformation}

The protein secondary structure is determined from the shape of the amide I band, located at $1660-1650 \mathrm{~cm}^{-1}$. The FTIR spectra were smoothed, and their baselines were adjusted using Peak Fit v4 software. The spectral region was deconvoluted with the Gaussian function, and the peaks were automatically fitted based on the least squares method. The fitting peaks correspond to an a-helix $\left(1646 \sim 1664 \mathrm{~cm}^{-1}\right), \beta$-sheet $\left(1615 \sim 1637 \mathrm{~cm}^{-1}\right.$ and 1682 1700 $\left.\mathrm{cm}^{-1}\right)$, $\beta$-turn $\left(1664 \sim 1681 \mathrm{~cm}^{-1}\right)$, and random coil conformations $\left(1637 \sim 1645 \mathrm{~cm}^{-1}\right)$.

\section{$X$-ray diffraction}

The X-ray diffractograms of DDC, DDC-1, DDC-2 were recorded using an X-ray diffractometer (D8 ADVANCE, Germany) with $\mathrm{Cu}$ radiation $(0.15418 \mathrm{~nm})$. The generator was used at $40 \mathrm{kV}$ and $40 \mathrm{~mA}$. Angular scanning was conducted from $5^{\circ}$ to $40^{\circ}$.

\section{Scanning electron microscopy (SEM) observations}

The microstructure of DDC, DDC-1, and DDC-2 were observed with SEM (EVO18, Germany).

\section{Intrinsic viscosity}

Viscometry was used to determine the intrinsic viscosity of DDC, DDC-1, and DDC-2. The samples were dissolved in a copper(II)-ethylenediamine/water solution $(1: 1, \mathrm{v} / \mathrm{v})$, and the flow time in a glass capillary viscometer (Ubbelohde, $\mathrm{f}=0.6 \mathrm{~mm}$ ) was measured. The intrinsic viscosity of the samples was calculated according to TAPPI T230 om-08 and (Munk \& Aminabhavi, 2002).

\subsection{Statistical analysis}

Unless otherwise specified, three independent trials were carried out-each used a new batch of sample preparation. The results are presented as the mean \pm standard deviation. Analysis of variance (ANOVA), specifically Duncan's multiple range tests was used and treatments were considered significantly different at $\mathrm{p}<0.05$.

Table 1. Samples with different conditions.

\begin{tabular}{ccccccccccc}
\hline Sample & DDC-1 & DDC-2 & DDC-3 & DDC-4 & DDC-5 & DDC-6 & DDC-7 & DDC-8 & DDC-9 & DDC-10 \\
\hline $\mathrm{pH}$ & 1.00 & 2.00 & 3.00 & 4.00 & 1.00 & 1.00 & 1.00 & 2.00 & 2.00 & 2.00 \\
Weight /g & 2.00 & 2.00 & 2.00 & 2.00 & 0.50 & 1.00 & 1.50 & 0.50 & 1.00 & 1.50 \\
\hline
\end{tabular}




\section{Results and discussion}

\subsection{Changes of $\mathrm{pH}$ and weight loss during hydrochloric acid hydrolysis}

\section{Influence of initial $\mathrm{pH}$}

Figure 1 shows the weight loss of DDC-1, DDC-2, DDC-3, DDC- 4 after $6 \mathrm{~h}$ hydrolysis. The results showed that the weight loss of DDC-1 was less than that of DDC-2, DDC-3, and DDC-4 suggesting that more insoluble dietary fiber was transformed into soluble dietary fiber in a more acidic environment. The results were similar to the acid hydrolysis of coconut meal in $0.5 \%-1.0 \%$ hydrochloric acid at $90^{\circ} \mathrm{C}$ (Thongsook \& Chaijamrus, 2014).

Figure 2 shows the $\mathrm{pH}$ changes of DDC-1, DDC-2, DDC-3, and DDC- 4 after $30 \mathrm{~s}$ and $6 \mathrm{~h}$ hydrolysis. From Figure 2 , the $\mathrm{pH}$ of the four samples hydrolysis systems increased after $30 \mathrm{~s}$. However, $6 \mathrm{~h}$ later, the $\mathrm{pH}$ of the DDC- 1 hydrolysis system declined, $\mathrm{pHs}$ of DDC-2, DDC-3, and DDC-4 hydrolysis system still increased. The hydrolysis of biopolymers in desiccated coconuts including cellulose and protein consumes large amounts of $\mathrm{H}^{+}$. This explains the $\mathrm{pH}$ increase. It is remarkable that the $\mathrm{pH}$ of DDC-1 digestive system declined $6 \mathrm{~h}$ later. This shows the effects of different starting conditions and is explained by the larger hydrolysis of desiccated coconut (shown in Figure 1). This hydrolysis is primarily of cellulose and protein.

In $\mathrm{pH}=1.00$ system, aldehyde acid, glucuronic acid and other uronic acid in the hemicellulose side chain was exfoliated by hydrolysis and acidic components were produced (Khuwijitjaru et al., 2012; Sjöström, 1993). This decreased the $\mathrm{pH}$ of DDC-1 hydrolysis system. In addition, the protein in desiccated coconut was hydrolyzed into large amounts of acidic amino acids (glutamic acid and aspartic acid) (Sulabo et al., 2013) by extensive hydrolysis. This lowers the $\mathrm{pH}$. In the acidic medium with $\mathrm{pH}=2.00,3.00$, or 4.00 , the production of organic acid and acidic amino acid was much lower because of the milder hydrolysis of desiccated coconut. The acidolysis consumes large amounts of $\mathrm{H}^{+}$and increases the $\mathrm{pH}$. The results suggested that eating desiccated coconut is not appropriate on an empty stomach with strong acid medium because it may lead to a heavy and upset stomach.

\section{The effect of DDC quantities}

Figure 3 shows the $\mathrm{pH}$ changes of hydrolysis systems of the samples with different quantities. From Figure 3 , the hydrolysis system $\mathrm{pH}$ still decreased in initial $\mathrm{pH}=1.00$ samples, even the quantity of DDC decreased by four-fold. And $\triangle \mathrm{pH}$ remained stable with different quantities of DDC. However, in the $\mathrm{pH}=2.00$ system, the $\Delta \mathrm{pH}$ increased with increasing quantities of DDC. This might be because the acidolysis occurred on the branched chain.

\subsection{Structure of ingredients of DDC}

\section{Degradation of DDC}

Table 2 showed the intrinsic viscosity of DDC, DDC-1, DDC-2. As shown in Table 2, after hydrolysis, the intrinsic viscosity of desiccated coconut decreased, and the descending range increased in higher $\mathrm{pH}$ system. Of note, the intrinsic viscosity of DDC-1 was the lowest. This suggested that most of

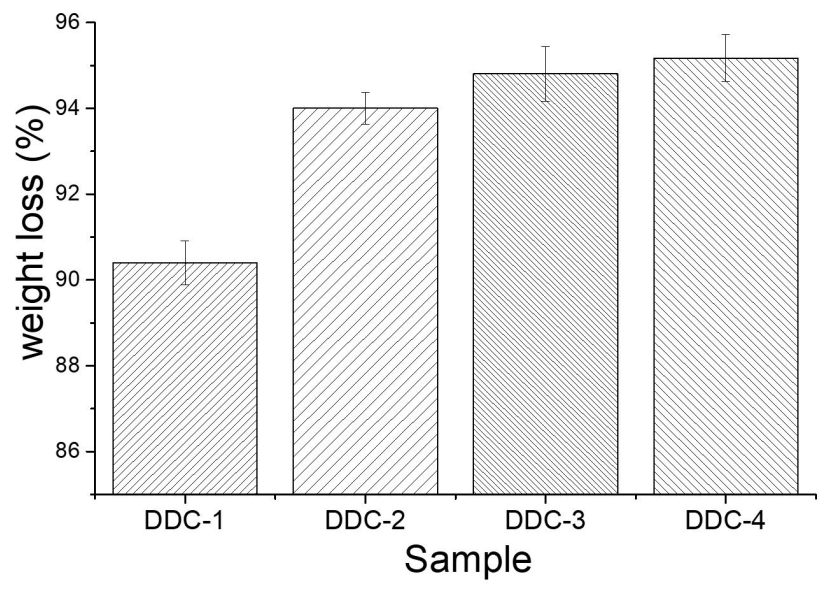

Figure 1. Weight loss of samples after hydrolysis $6 \mathrm{~h}$.

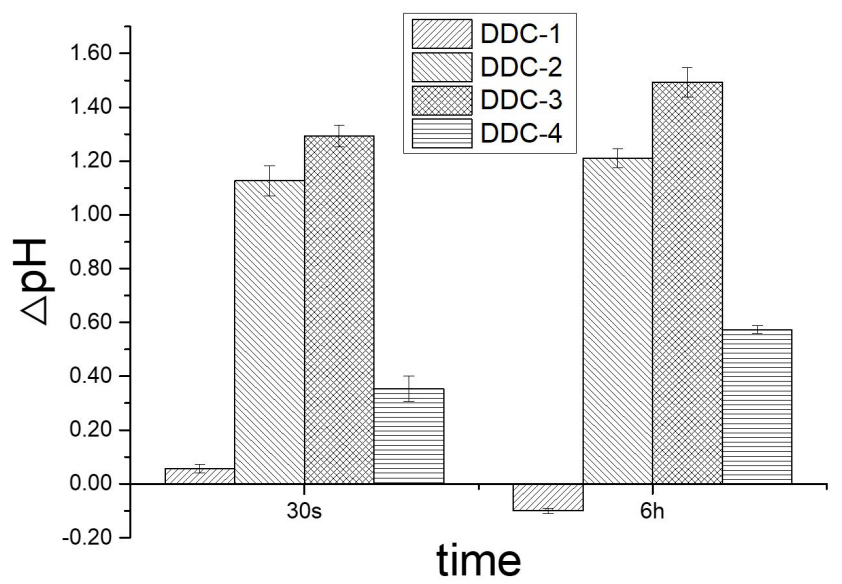

Figure 2. changes of $\mathrm{pH}$ of DDC-1, DDC-2, DDC-3, and DDC-4 hydrolysis systems after hydrolysis $30 \mathrm{~s}$ and $6 \mathrm{~h}$.

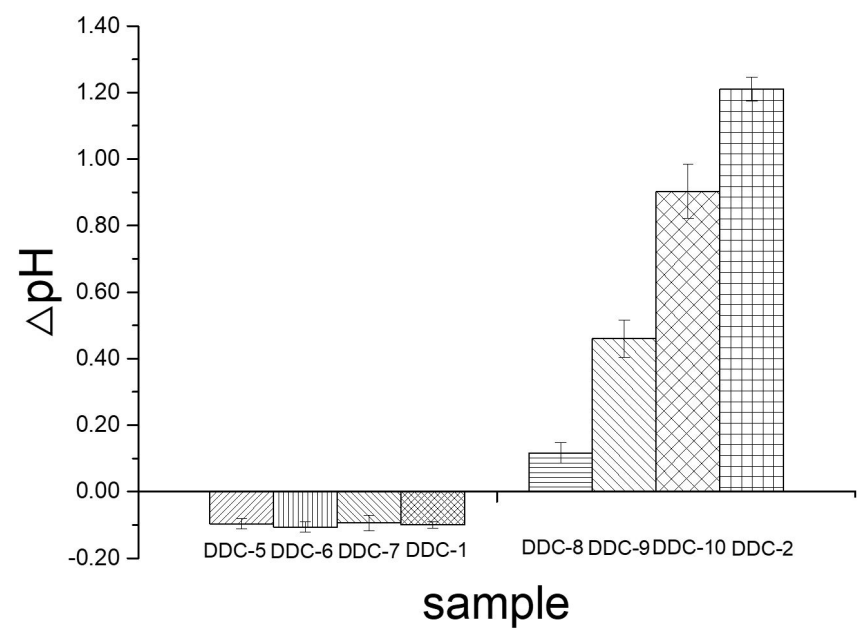

Figure 3. The changes of hydrolysis system pHs of some samples.

Table 2. Intrinsic viscosity of DDC, DDC-1, and DDC-2.

\begin{tabular}{cc}
\hline Sample & intrinsic viscosity $(\mathrm{mL} / \mathrm{g})^{\star}$ \\
\hline DDC & 110.580 \\
DDC-1 & 0.397 \\
DDC-2 & 93.608 \\
\hline
\end{tabular}

${ }^{*}$ Data are expressed as mean \pm standard deviation $(n=3) . P \leq 0.05$. 
its macromolecular chain was hydrolyzed. The glucosidic bonds of the hemicellulose and insoluble pectin in desiccated coconut were ruptured in the acid medium. This helped to transform part of the insoluble fiber to soluble fiber. The results supported in the deduction of decomposition of cellulose and protein by hydrolysis (shown in section 2.1.1).

\section{FTIR spectroscopy}

The FTIR spectra of DDC, DDC-1, and DDC-2 are shown in Figure 4. In the FTIR spectra of DDC, The $\mathrm{OH}$ stretching band was at $3445 \mathrm{~cm}^{-1}$ and it became narrow and shifted to lower
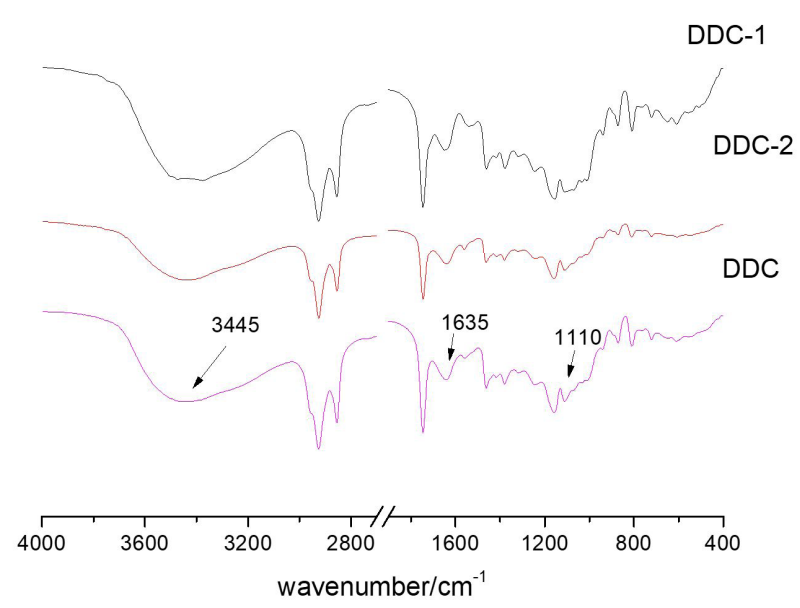

Figure 4. FTIR spectra of DDC, DDC-1, and DDC-2.
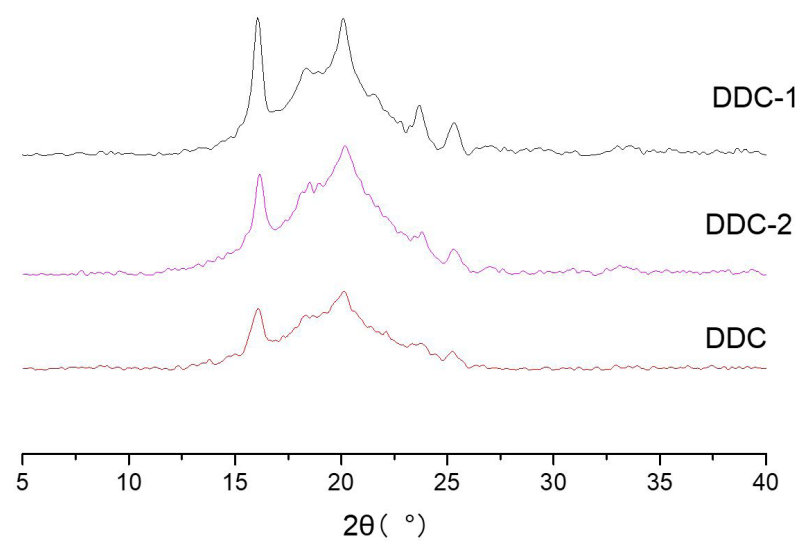

Figure 5. The XRD patterns of DDC, DDC-1, and DDC-2. wavenumbers as initial $\mathrm{pH}$ decreased. This confirmed changes in the intramolecular hydrogen bonding (Thongsook \& Chaijamrus, 2014). The NH stretching was at $1635 \mathrm{~cm}^{-1}$ suggesting the presence of protein. The peak at $1743 \mathrm{~cm}^{-1}$ represented vibrations of acetyl and uronic ester groups of hemicelluloses or ester linkage of carboxylic group of the ferulic and p-coumaric acids of lignin (Zuluaga et al., 2009). The absorption peak of C-O-C at $1110 \mathrm{~cm}^{-1}$ became weaker, which illustrated that hydrochloric acid could destroy the structure of the lignocellulose via hydrolyzing glucosidic bonds (Mosier et al., 2005).

\section{$X$-ray diffraction}

The X-ray diffraction (XRD) pattern of DDC, DDC-1, and DDC-2 are shown in Figure 5. The results suggest that DDC, DDC-1, and DDC-2 had similar crystalline structure. The crystallinity of DDC, DDC-1, and DDC- 2 were calculated automatically by JADE 5.0 software to be $14.00 \%, 27.25 \%$, and $47.63 \%$, respectively. This demonstrated that the crystallinity of desiccated coconut could increase by hydrolysis. These results revealed that the hydrolysis of desiccated coconut mainly occurred in non-crystalline regions.

\section{Change of secondary structure of coconut protein during hydrolysis}

In the FTIR spectra of DDC, DDC-1, and DDC-2, the protein secondary structure was analyzed from the shape of the amide I band located at $1660-1650 \mathrm{~cm}^{-1}$. Curve fitting and quantitative analysis of the protein secondary structure for DDC, DDC-1, and DDC- are shown in Figure 6 and Table 3. In Figure 6, four fitting peaks of DDC-2 remained the same in contrast to DDC. That of DDC-1 shifted to lower wavenumbers. This revealed that the interaction between $\mathrm{C}=\mathrm{O}$ and $\mathrm{N}-\mathrm{H}$ in the protein main chain was strengthened after hydrolysis. The contents of a-helix, $\beta$-sheet, $\beta$-turn, and random turns in DDC-2 remained the same versus DDC (Table 3 ). The amount of random turns in DDC-1 decreased while other secondary structures increased. This indicated that the protein structure become more stable after hydrolysis in a strong acidic digestive system (Kanakis et al., 2011).
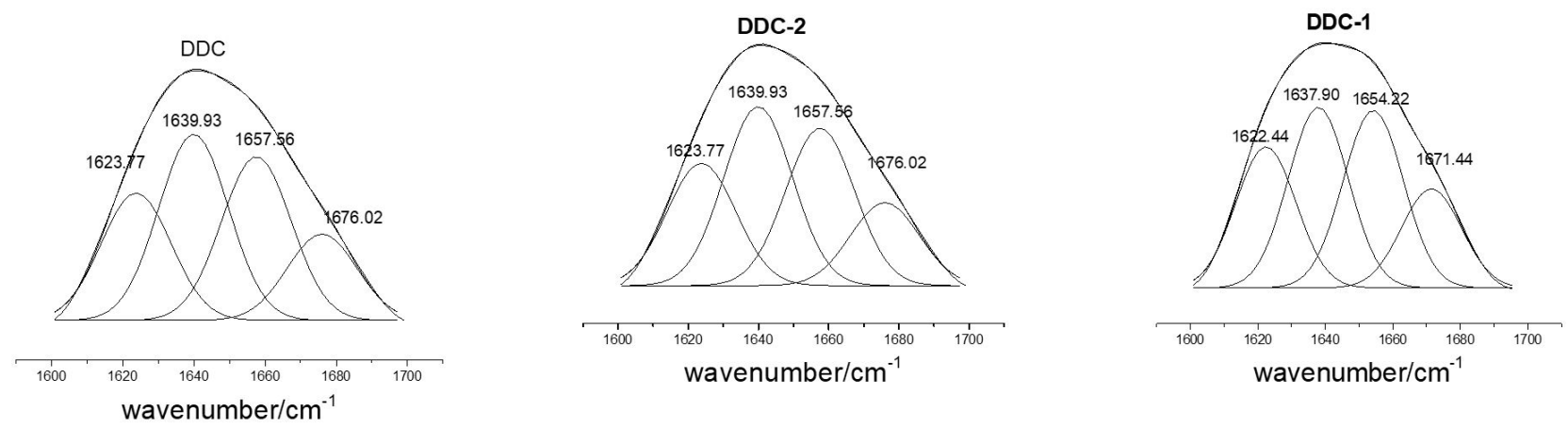

Figure 6. Deconvolution and curve-fitted amide I region (1600-1700 $\left.\mathrm{cm}^{-1}\right)$ for DDC, DDC-1, and DDC-2. 

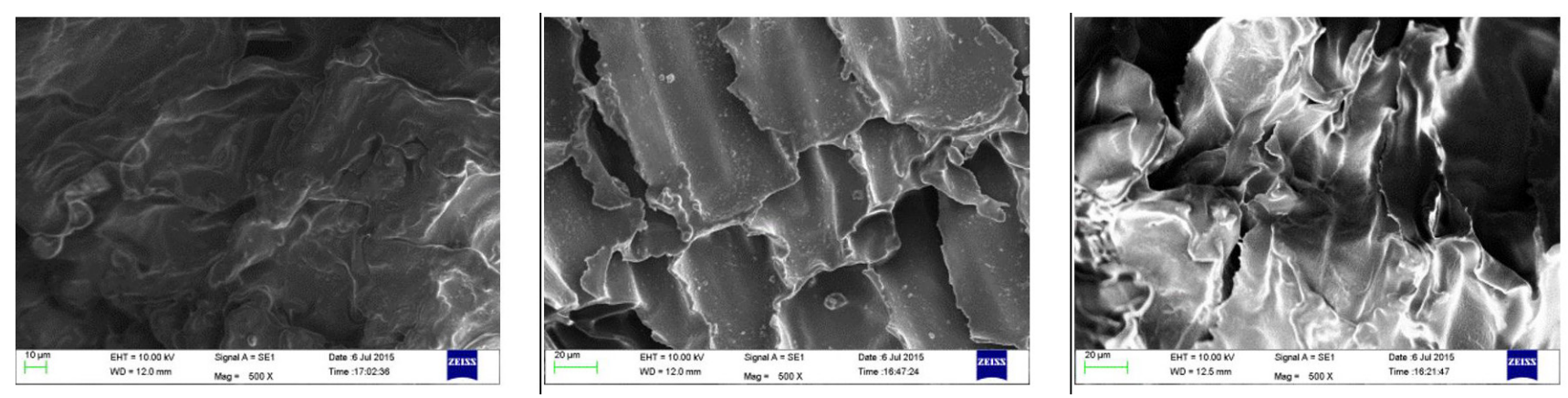

Figure 7. SEM images of the microstructure of DDC, DDC-1, and DDC-2.

Table 3. Secondary structure analysis for DDC,DDC-1, and DDC-2.

\begin{tabular}{ccccc}
\hline Sample & $\beta$-sheet & Random & a-helix & $\beta$-turn \\
\hline DDC & $22.59 \%$ & $33.03 \%$ & $29.06 \%$ & $15.32 \%$ \\
DDC-1 & $23.57 \%$ & $30.18 \%$ & $29.68 \%$ & $16.56 \%$ \\
DDC-2 & $22.59 \%$ & $33.03 \%$ & $29.06 \%$ & $15.32 \%$ \\
\hline
\end{tabular}

\section{Microstructure}

The microstructure of DDC, DDC-1, and DDC-2 were observed with SEM. As shown in Figure 7, the surface of DDC is smooth and crack-free, but when treated in a $\mathrm{pH}=2.00$ digestive system, the surface of the DDC- 2 cracked and delaminated to form orderly stripe-like channels. As the digestive medium becomes more acidic, the stripe-like channel structures were destroyed and irregular channels were exposed on the surface of DDC-1. This could be attributed to the transformation from insoluble lignocellulose into soluble lignocellulose (Mosier et al., 2005), which was testified by the analysis of FTIR (shown in 2.2.2). These results revealed that the $\mathrm{pH}$ of digestive system played an important role in the microstructure destruction and insoluble lignocellulose translation in desiccated coconut.

\section{Conclusions}

The hydrolysis by hydrochloric acid was employed on defatted desiccated coconut. The results showed that there are strongly different changes of $\mathrm{pHs}$ with different initial $\mathrm{pHs}$ acidic hydrolysis systems. The $\mathrm{pH}$ in initial $\mathrm{pH}=1.00$ system decreased after $6 \mathrm{~h}$ hydrolysis, because of extensive hydrolysis of lignocellulose and protein in desiccated coconut. We found that the hydrolysis of desiccated coconut mainly occurred in branched chains and in the amorphous region of the lignocellulose. The desiccated coconut digested in more acidic medium had a smaller intrinsic viscosity, higher crystalline, looser microstructure, and more stable secondary protein structure.

\section{Acknowledgements}

We gratefully acknowledge the financial support provided by State Key Laboratory of Pulp and Paper Engineering (Project 2016C12) and the National Natural Foundation of China (project 31270617). The authors also thank Deborah Teague for English editing assistance.

\section{References}

Brown, L., Rosner, B., Willett, W. W., \& Sacks, F. M. (1999). Cholesterollowering effects of dietary fiber: a meta-analysis. The American Journal of Clinical Nutrition, 69(1), 30-42. PMid:9925120.

Corcoran, B. M., Stanton, C., Fitzgerald, G. F., \& Ross, R. P. (2007). Growth of probiotic lactobacilli in the presence of oleic acid enhances subsequent survival in gastric juice. Microbiology, 153(Pt 1), 291-299. PMid:17185558. http://dx.doi.org/10.1099/mic.0.28966-0.

DebMandal, M., \& Mandal, S. (2011). Coconut (Cocos nucifera L.: Arecaceae): in health promotion and disease prevention. Asian Pacific Journal of Tropical Medicine, 4(3), 241-247. PMid:21771462. http://dx.doi.org/10.1016/S1995-7645(11)60078-3.

Gallaher, D. D. (2006). Dietary fiber. Washington, D.C.: ILSI Press.

Kaczmarczyk, M. M., Miller, M. J., \& Freund, G. G. (2012). The health benefits of dietary fiber: beyond the usual suspects of type 2 diabetes mellitus, cardiovascular disease and colon cancer. Metabolism: Clinical and Experimental, 61(8), 1058-1066. PMid:22401879. http://dx.doi. org/10.1016/j.metabol.2012.01.017.

Kanakis, C., Hasni, I., Bourassa, P., Tarantilis, P., Polissiou, M., \& Tajmir-Riahi, H.-A. (2011). Milk $\beta$-lactoglobulin complexes with tea polyphenols. Food Chemistry, 127(3), 1046-1055. PMid:25214095. http://dx.doi.org/10.1016/j.foodchem.2011.01.079.

Khuwijitjaru, P., Pokpong, A., Klinchongkon, K., \& Adachi, S. (2014). Production of oligosaccharides from coconut meal by subcritical water treatment. International Journal of Food Science \& Technology, 49(8), 1946-1952. http://dx.doi.org/10.1111/ijfs.12524.

Khuwijitjaru, P., Watsanit, K., \& Adachi, S. (2012). Carbohydrate content and composition of product from subcritical water treatment of coconut meal. Journal of Industrial and Engineering Chemistry, 18(1), 225-229. http://dx.doi.org/10.1016/j.jiec.2011.11.010.

Lalush, I., Bar, H., Zakaria, I., Eichler, S., \& Shimoni, E. (2005). Utilization of amylose-lipid complexes as molecular nanocapsules for conjugated linoleic Acid. Biomacromolecules, 6(1), 121-130. PMid:15638512. http://dx.doi.org/10.1021/bm049644f.

Marieb, E. N., \& Hoehn, K. (2010). Human anatomy \& physiology. San Francisco: Benjamin Cummings.

Marotti, I., Bregola, V., Aloisio, I., Di Gioia, D., Bosi, S., Di Silvestro, R., Quinn, R., \& Dinelli, G. (2012). Prebiotic effect of soluble fibres from modern and old durum-type wheat varieties on Lactobacillus and Bifidobacterium strains. Journal of the Science of Food and Agriculture, 92(10), 2133-2140. PMid:22298124. http://dx.doi. org/10.1002/jsfa.5597.

Mosier, N., Wyman, C., Dale, B., Elander, R., Lee, Y. Y., Holtzapple, M., \& Ladisch, M. (2005). Features of promising technologies for 
pretreatment of lignocellulosic biomass. Bioresource, 96(6), 673-686. PMid:15588770. http://dx.doi.org/10.1016/j.biortech.2004.06.025.

Munk, P., \& Aminabhavi, T. M. (2002). Introduction to macromolecular science (2nd ed.). New York: Wiley.

Park, Y., Subar, A. F., Hollenbeck, A., \& Schatzkin, A. (2011). Dietary fiber intake and mortality in the NIH-AARP diet and health study. Archives of Internal Medicine, 171(12), 1061-1068. PMid:21321288. http://dx.doi.org/10.1001/archinternmed.2011.18.

Pham, C. B., \& Rosario, R. D. (1983). The preparation of protein hydrolysate from defatted coconut and soybean meals. International Journal of Food Science \& Technology, 18(1), 21-34.

Silva, S. Q., Santos, M. T., Paes, S. A., \& Vanetti, M. C. D. (2016). Acid and low temperature treatments on Salmonella Enteritidis inoculated in pork and its subsequent survival in simulated gastric fluid. Microbiology, 46, 530-535.

Sjöström, E. (1993). Wood chemistry: fundamentals and applications. Houston: Gulf Professional Publishing.

Sulabo, R., Ju, W., \& Stein, H. (2013). Amino acid digestibility and concentration of digestible and metabolizable energy in copra meal, palm kernel expellers, and palm kernel meal fed to growing pigs. Journal of Animal Science, 91(3), 1391-1399. PMid:23307844. http:// dx.doi.org/10.2527/jas.2012-5281.
The United States Pharmacopeia - USP. (1995). Simulated gastric fluid and simulated intestinal fluid, TS (The National Formulary, Vol. 23). Rockville: The United States Pharmacopeia.

Thongsook, T., \& Chaijamrus, S. (2014). Modification of physiochemical properties of copra meal by dilute acid hydrolysis. International Journal of Food Science \& Technology, 49(6), 1461-1469. http:// dx.doi.org/10.1111/ijfs.12440.

Trinidad, T. P., Mallillin, A. C., Valdez, D. H., Loyola, A. S., AskaliMercado, F. C., Castillo, J. C., Encabo, R. R., Masa, D. B., Maglaya, A. S., \& Chua, M. T. (2006). Dietary fiber from coconut flour: a functional food. Innovative Food Science \& Emerging Technologies, 7(4), 309-317. http://dx.doi.org/10.1016/j.ifset.2004.04.003.

Yapo, B. M., \& Koffi, K. L. (2008). Dietary fiber components in yellow passion fruit rind: a potential fiber source. Journal of Agricultural and Food Chemistry, 56(14), 5880-5883. PMid:18558700. http:// dx.doi.org/10.1021/jf073247p.

Zuluaga, R., Putaux, J. L., Cruz, J., Vélez, J., Mondragon, I., \& Gañán, P. (2009). Cellulose microfibrils from banana rachis: effect of alkaline treatments on structural and morphological features. Carbohydrate Polymers, 76(1), 51-59. http://dx.doi.org/10.1016/j. carbpol.2008.09.024. 